\title{
The Investigative Scope of Article 8(2)(b)(viii) of the Rome Statute before the ICC within the Palestine Situation
}

\author{
Geert-Jan Alexander Knoops
}

Professor of Politics of International Law, University of Amsterdam, Amsterdam, The Netherlands; Visiting Professor of International Criminal Law, Shandong University, Jinan, China; lawyer, international criminal law, Knoops' International Lawyers, Amsterdam, The Netherlands

\section{Ine van Giessen}

Legal assistant and researcher, Knoops' International Lawyers, Amsterdam, The Netherlands

\begin{abstract}
This article aims to analyse the pitfalls and prospects of the preliminary examinations Prosecutor's Office of the International Criminal Court (отP) into the situation in Palestine. The отр opened the preliminary examination into the situation in Palestine on 16 January 2015 covering the timeframe as of 13 June 2014, the start of Israel's military operation - 'Protective Edge' - into Gaza. The request of Palestine to investigate aims also at alleged crimes committed on 'occupied territories' by Israel. One of the most pertinent questions will be the basis upon which the отр is to determine this qualification of occupied territories. The authors introduce legal rights to the territories, through a teleological interpretation of Art. 21(1)(b).

Rome Statute, within the prosecutorial test of Art. 53(1) Rome Statute, i.e. the existence of 'a reasonable basis to proceed' to initiate an investigation.
\end{abstract}

* The authors are indebted to Mr. Pepijn van der Vegt, research assistant at Knoops' International Lawyers, for his remarkable research assistance.

(C) GEERT-JAN ALEXANDER KNOOPS AND INE VAN GIESSEN, 2018 | DOI 10.1163/15718123-01706002 This is an open access article distributed under the terms of the prevailing CC-BY-NC License at the time of publication. 


\section{Keywords}

international criminal law (ICL) - preliminary examination - Palestine - Israel - San Remo - occupied territories - International Criminal Court (ICC) - Balfour Declaration

\section{Introduction}

Probably one of the most legally and politically sensitive preliminary examinations currently pending before the International Criminal Court (ICC), is that of Palestine. In 2015, the Office of the Prosecutor (ОTP) announced they would open a preliminary examination into the situation in Palestine. ${ }^{1}$ The preliminary examination aims at a potential investigation of alleged crimes committed in Gaza and the West Bank in order to discern whether a reasonable basis to proceed with a formal investigation exists. ${ }^{2}$ According to the Report on Preliminary Examinations Activities of 2016 of the отP (hereafter: the Report), the subject-matter of said examination also entails crimes committed in the 'occupied territories. ${ }^{3}$ The land and settlement issues that lie at the heart of the Palestine/Israeli conflict may play a substantial role in the examination. The claim of both Palestine and Israel to the same territory goes back decades, with both parties leaning on historical contexts to validate their territorial claims. A substantial part of the conflict pertains to the settlement activities by the Israeli government on supposed Palestinian territory. A number of alleged crimes that could potentially qualify as war crimes under Article 8 Rome Statute as set forth in the Report, were allegedly committed in the 'occupied territories'. ${ }^{4}$

One of the most pertinent questions relates to the legal and factual basis upon which the отP is to determine whether the West bank is to be considered 'occupied territory'. It will be interesting to observe whether the отP is willing and able to balance the historical context regarding the territories with its legal considerations. In particular, one pivotal question pertains to whether the test of Article 53(1) Rome Statute is (also) to be determined on the basis of Article 21(1)(b) Rome Statute, i.e., the reference to 'applicable treaties'. This

1 International Criminal Court, "The Prosecutor of the International Criminal Court Fatou Bensouda, opens a Preliminary Examination of the Situation in Palestine', press release, 16 January 2015, <www.icc-cpi.int//Pages/item.aspx?name=pr1083>, 23 August 2017.

2 Article 53 Rome Statute.

3 International Criminal Court, The Office of the Prosecutor, Report on Preliminary Examination Activities 2016 (14 November 2016), <www.icc-cpi.int/iccdocs/otp/161114-otp-rep-PE _ENG.pdf $>, 18$ August 2017.

4 Ibid., para. 130. 
question merits thought now that the discussion regarding the West Bank revolves around several treaties that were adopted in 1920 and 1922. Doctrinal research reveals the potential relevance of such treaties triggered by or based on historical findings for the legal qualification to be transposed onto the situation in the West Bank.

One book in which these historical data and subsequent treaties were unravelled was published in 2007 by the Canadian scholar, Dr. Jacques Paul Gauthier. At the outset of his dissertation on the sovereignty over the old city of Jerusalem, Gautier observes that ' $[\mathrm{t}]$ he refusal or reluctance to take into consideration these facts (i.e. the historical facts of the case of Jerusalem and its Old City; GJK) has contributed to the repeated failures of the different phases of the Middle East peace process. 5 This conclusion by Gauthier expresses the potential relevance of the inclusion of historical data for the examinations by the отр. It goes without saying that a successful outcome of the Middle East peace process depending on historical context falls outside the ambit of the law, yet these historical data may justify the application of Article 21(1)(b) Rome Statute. Other authors, such as Ilan Dunsky who Gauthier cites, share Gauthier's view on this matter. Dunsky avers that to examine 'only one part of the claim, or of one historical period, to the exclusion of another, ignores aspects which are essential to a true understanding of the conflict.' 6

If one accepts that historical context can play a substantive role when ascertaining the territorial claims that have culminated in treaty law, the question arises whether the ОтP, within the context of Article 53(1) Rome Statute, can and should rely on such historical context. As a result, this article will delve into the main research question as to whether the Article 53(1) Rome Statute test should give due regard to the historical boundaries of the disputed territories in the West Bank as evidenced by treaties of 1920 and 1922. If these treaties are still to be considered as primary sources of international law within the meaning of Article 21 Rome Statute, the question arises whether the отр is bound to apply them within the context of Article 53(1) Rome Statute. The relevance of this question is that the отр currently examines a possible infraction of Article $8(2)(\mathrm{b})$ (viii) Rome Statute in this regard. The starting point of this article is the discretionary power of the отP to examine the Palestine situation. Yet these powers can be confined by the sources as enumerated by Article 21(1) Rome Statute. However, it is to be determined whether Article 21(1) Rome Statute

5 Jacques Paul Gauthier, Sovereignty over the Old City of Jerusalem: A Study of the Historical, Religious, Political and Legal Aspects of the Question of the Old City (Universite de Geneve, Geneva, 2007), p. 9.

6 Ilan Dunsky, 'Israel, the Arabs, and international law: Whose Palestine is it, anyway?', 2 Dalhousie Journal of Legal Studies (1992) 163-200, at p. 164 as cited in: ibid., p. 10. 
transgresses into Article 53(1) Rome Statute. In order to assess these boundaries, in Section 1 we will address the (legal) events of potential importance to the territorial claims that underline the potential crimes the отр has listed in its preliminary examination report. Section 2 delves into legal analysis of the (historical) treaties of 1920 and 1922 to assess whether legal standing can still be accrued to them within the ambit of the ICC's preliminary examination. It touches upon the interrelationship between historical context and legal conclusions. The third section examines the legal ambit of Article 8(2)(b)(viii) Rome Statute, which provision is potentially applied by the отр when assessing the situation in the 'occupied territories'. This, of course, presupposes the legal acceptance of 'occupation' in the West Bank. The extent to which Article $8(2)(b)$ (viii) is interpreted in the traveaux preparatoires, illustrates the importance of the primary question, i.e. whether a situation of 'occupation' occurs.

So long as there are men, there will be wars

ALBERT EINSTEIN

In order to understand the potential relevance and transposition of the mentioned treaties onto Article 53(1) Rome Statute, this section will at first address the events that underlie these treaties. In the course of the First World War, the Ottoman Empire joined Germany in their alliance against France, Russia, the British Empire and their allies. ${ }^{7}$ On 11 December 1917, the British forces, under command of General Edmund Allenby, entered the City of Jerusalem after its abandonment by the Turks on 9 December $1917 .{ }^{8}$ With the defeat of Germany and the Ottoman Empire, the Ottomans lost their land, and the Middle East simultaneously lost its ruler. The fall of the Ottoman Empire cleared room for two groups to fulfil their aspirations, as they had previously been deprived of their independence; the Arab and Jewish peoples. A few weeks prior to the entry of the British forces in Jerusalem, the Secretary of State for Foreign Affairs of Great Britain, Mr. Balfour wrote a letter to Baron Lionel Walter de Rothschild. ${ }^{9}$ The Rothschild family was arguably one of the most influential Jewish families at that time. The letter of 2 November 1917 read:

\footnotetext{
7 Ibid., p. 229.

8 Ibid., p. 230.

9 Ibid., p. 271.
} 
$[\mathrm{H}]$ is Majesty's Government view with favour the establishment in Palestine of a national home for the Jewish people, and will use their best endeavours to facilitate the achievement of this object, it being clearly understood that nothing shall be done which may prejudice the civil and religious rights of existing non-Jewish communities in Palestine, or the rights and political status enjoyed by Jews in any other country. ${ }^{10}$

This letter portrayed the formal support of Great Britain for the establishment of a Jewish homeland and later became known as the Balfour Declaration. ${ }^{11} \mathrm{On}$ 26 April, the British Government released a statement saying that it is proud to have issued the Balfour Declaration. ${ }^{12}$ One year before the Balfour Declaration, during the First World War in 1916, Great Britain and France had defined their mutually agreed scope of control and influence in Southwestern Asia in a secret document known as the Sykes-Picot Agreement. Syria and Lebanon would fall under French command and most of Mesopotamia would fall under the control of Great Britain. Palestine, on the other hand would be overseen by an international body. ${ }^{13}$ The Agreement was based on the assumption that the Allies would be successful in the defeat of the Ottoman Empire. Ultimately, this was the outcome of the war.

After the First World War, the Allied Powers met at the Paris Peace Conference of 1919 to set peace terms for the defeated powers. During this conference, the Allied Powers prepared five major peace treaties. Both the Arabs and the Zionist Organization presented their cases and view for the future of Palestine. The Zionist Organization asked for 'the recognition of the historic title of the Jewish people in Palestine and the right of Jews to reconstitute their national home.14

The Covenant of the League of Nations (hereafter: the Covenant) was another result of the Paris Peace Conference, its final text was adopted on 28 April 1919. Article 22 of the Covenant included the decision of the Supreme

10 Balfour Declaration, 2 November 2017, <www.avalon.law.yale.edu/2oth_century/balfour .asp $>, 23$ August 2017.

11 Gauthier, supra note 5, p. 273.

12 Petition UK Government and Parliament, UK Must Apologise for the Balfour Declaration \& Lead Peace Efforts in Palestine (closed 3 May 2017), www.petition.parliament.uk/ petitions/184398?reveal_response=yes, 23 May 2017.

13 Lord Leslie Turnberg, Beyond the Balfour Declaration (Biteback Publishing, London, 2017), p. 10.

14 Gauthier, cited in: Yosef Mazur, Zionism, Post-Zionism \& the Arab Problem: A Compendium of Opinions about the Jewish State, Mike Cohen (ed.) (Westbow Press, Bloomington, 2012), p. 193. 
Council of the Allied Powers to establish an international mandate system to divide the former German and Ottoman territories. ${ }^{15}$ The League of Nations awarded the German and Ottoman possessions overseas, as mandates, to the members of the British and the French empire. ${ }^{16}$

On 25 April 1920, the Supreme Council of the Allied Powers convened in San Remo to further formally discuss and decide on the disposition of the Middle East territories previously held by the Ottoman Empire. The text of the resolution held that:

The High Contracting Parties agree to entrust, by application of the provisions of Article 22, the administration of Palestine, within such boundaries as may be determined by the Principal Allied Powers, to a Mandatory, to be selected by the said Powers. The Mandatory will be responsible for putting into effect the declaration originally made on November 8, 1917, by the British Government, and adopted by the other Allied Powers, in favour of the establishment in Palestine of a national home for the Jewish people, it being clearly understood that nothing shall be done which may prejudice the civil and religious rights of existing non-Jewish communities in Palestine, or the rights and political status enjoyed by Jews in any other country. ${ }^{17}$

The resolution directly referred to the Balfour Declaration by which the Declaration became an international legal act and was approved by the signatories. ${ }^{18}$ Furthermore, the Allied Powers agreed that the League of Nations should give Britain a mandate over the area (now Israel, Jordan and the Golan Heights) that would be named 'the Mandate of Palestine' (hereafter: the Mandate). Thus, the Supreme Council made the formal decision to give France and Great Britain mandates as discussed previously during the Paris Peace Conference, resulting in the reduction of the area that would, according to the Sykes-Picot Agreement, be put under the control of France. ${ }^{19}$ On 24 July 1922, the Council of the League of Nations formally entrusted the Mandate of Palestine to

15 Gautier, supra note 5, p. 360.

16 The Origins and Evolution of the Palestine Problem: 1917-1988, the Committee on the Exercise of the Inalienable Rights of the Palestinian People, Part. II, <www.unispal.un.org/ DPA/DPR/unispal.nsf/5ba47a5c6cef541b8o2563eooo493b8c/d442111e70e417e3802564740o 45a309? OpenDocument $>18$ August 2017; United Nations, The Origins and Evolution of the Palestine Problem: 1917-1988 (New York: United Nations, 1990).

17 Supreme Council of the Allied Powers, Conference of San Remo, 25 April 1920.

18 Gauthier, supra note 5, pp. 368-369.

19 Ibid., p. 369. 
Britain in the 'Palestine Mandate'. ${ }^{20}$ In the preamble of the Palestine Mandate, the Council of the League of Nations directly refers to the Balfour declaration by stating that:

The Mandatory should be responsible for putting into effect the declaration originally made on November $2 n d, 1917$ (emphasis added; GJK), by the Government of His Britannic Majesty, and adopted by the said Powers, in favour of the establishment in Palestine of a national home for the Jewish people, it being clearly understood that nothing should be done which might prejudice the civil and religious rights of existing non-Jewish communities in Palestine, or the rights and political status enjoyed by Jews in any other country. ${ }^{21}$

After the Second World War, the League of Nations dissolved, and the United Nations was established. Importantly, Article 80 un Charter did not alter or modify the rights secured or acquired by any people or state under existing mandate instruments. ${ }^{22}$ Due to the protection of the rights of the Jewish people under the Mandate in combination with Article 80 un Charter, the UN could not acquire rights in Palestine that did not belong to the League of Nations. ${ }^{23}$ Therefore, under the UN system, the UN did not acquire the right to alter the allocation of a Jewish National Home throughout Palestine, including Jerusalem and its Old City without the consent of the people protected by the terms of the Mandate. ${ }^{24}$ The suggestion of a UN trusteeship for Palestine was raised on multiple occasions, most notably when us President Truman put forth a proposal to that end on 25 March 1948. Upon the decision of the UK to withdraw from Palestine, it had become clear that neither Israeli nor Arab leadership sufficiently supported the American proposal for it to be submitted to the UN General Assembly. Also in later years, Palestine was never placed under the UN trusteeship system. ${ }^{25}$

Article 80 UN Charter safeguards the rights conferred on the people under mandate. The ICJ accepts and applies this line of argumentation with respect to the status of rights and obligations deriving from a mandate after

\footnotetext{
20 Ibid., p. 388; League of Nations, Mandate for Palestine (1922) C. 529, M. 314, VI.

21 Mandate for Palestine, League of Nations, $\mathrm{C}_{529} \mathrm{M}_{314} \mathrm{VI}$ (12 August 1922).

22 Article 8o United Nations Charter; Gauthier, supra note 5, pp. 832, 834.

23 Ibid., p. 834 .

24 Ibid., pp. 832, 834.

25 Steven Spiegel, The Other Arab-Israeli Conflict (The University of Chicago Press, Chicago, 1985), pp. 34-35.
} 
the dissolving of the League of Nations. This follows from the ICJ's Advisory Opinion (AO) in the case of the International Status of South-West Africa of 1950, in which the ICJ held that the degree of the supervisory functions of the UN General Assembly (UNGA) should not exceed those applied under the Mandate System. ${ }^{26}$

During the final session of the League of Nations in 1946, a resolution had been passed declaring that the responsibilities and functions of the League of Nations with respect to the territories, that at that time were still under a mandate, would be discontinued without this leading to a transfer of said rights, functions of responsibilities to the United Nations (UN) or any other international entity'.27 After the UNGA adopted the resolution to partition Palestine on 29 November 1947; Resolution 181, Great Britain announced the termination of its Mandate over Palestine, to take effect on 15 May 1948..$^{28}$ While 33 states voted in favour of the resolution, 13 states voted against, amongst which were mostly Arab States: Afghanistan, Cuba, Egypt, Greece, India, Iran, Iraq, Lebanon, Pakistan, Saudi Arabia, Syria, Turkey and Yemen. ${ }^{29}$ On 14 May 1948, the State of Israel was proclaimed. ${ }^{30}$

Immediately after Israel's Declaration of Independence, five surrounding Arab nations invaded the new state. ${ }^{31}$ By the time that hostilities ceased, Israel had lost some of its territory to the attackers - the Golan Heights to Syria, Judea and Samaria (including the eastern part of Jerusalem) to Trans-Jordan, and the Gaza Strip to Egypt. However, pursuant to the principles of international law, it is unlawful to acquire territory by attacking another country. Trans-Jordan annexed Judea and Samaria into the West Bank. Syria and Egypt only occupied their captured territories. ${ }^{32}$

26 South-West Africa cases, 11 July 1950, International Court of Justice, Advisory Opinion Concerning the International Status, pp. 13-14, <www.icj-cij.org/files/case-related/10/010 -19500711-ADV-o1-oo-EN.pdf>, 18 August 2017.

27 Gauthier, supra note 5, p. 560.

28 United Nations General Assembly, Resolution 181(ii) (A/REs/181(II)); Gauthier, ibid., pp. $577-580,598$.

29 United Nations General Assembly, Resolution 181 (Partition Plan) (A/RES/181 (i)), <www .mfa.gov.il/mfa/foreignpolicy/peace/guide/pages/un\%2ogeneral\%2oassembly\%2oreso lution\%20181.aspx>, 18 July 2017.

30 Israel Ministry of Foreign Affairs, Declaration of Establishment of State of Israel (14 May 1948 ) <www.mfa.gov.il/mfa/foreignpolicy/peace/guide/pages/declaration\%2oof\%20 establishment\%2oof\%2ostate\%2oof\%2oisrael.aspx>, 5 May 2017.

31 Gauthier, supra note 5, p. 617.

32 Ibid., pp. 617-624. 
Arguably, Israel recaptured the territories it lost during the 1948 ArabIsraeli War. Pursuant to the San Remo resolution, the reclaimed territories had belonged to the Mandate, which in return resulted in the State of Israel. ${ }^{33}$ Since 1967 , Israel has allowed its citizens to live in settlements in the reclaimed territories. The international community considers this policy illegal. This raises the applicability of Article 8(2)(b)(viii) Rome Statute, which penalizes the transfer of population into occupied territories. On the other hand, the afore- mentioned treaties challenge the notion of an occupied territory regarding the territories at hand. The exact boundaries of the land covered by the Mandate were not defined at the San Remo conference. The Mandate did not undergo any modifications since 1948, thus arguably, the provisions of the Mandate could still be applicable to the entirety of Palestine west of the Jordan River, West Bank, and Gaza. This observation might be relevant for potential ICC proceedings.

\section{Transgression of Treaty Law into Article 53(1) Rome Statute}

The analysis in the preceding section triggers the question whether one could make a persuasive argument as to why the instruments of 1920 and 1922 could be considered as treaties, and therefore have legal standing. In order for these treaties to have any legal impact on a case before the ICC, the question whether their legal binding force is still applicable needs to be answered.

\subsection{Introduction}

In order for the отр to be able to pursue prosecution for an alleged violation of Article 8(2)(b)(viii) of the Rome Statute, the oтP needs to establish that the West Bank qualifies as an 'occupied territory'. The ICC can only arrive at this qualification when it thoroughly examines the legal status of the West Bank, applying the legal instruments it is bound to and at liberty to employ. These instruments are enumerated in Article 21(1) of the Rome Statute.

In the first place, the Court applies its own Statute and Rules of Procedure and Evidence (Section (1)(a)). The primacy of these sources is warranted by the principle of nullum crimen sine lege, as illustrated by the comprehensive nature of the Statute, elaborating both the criminal offences under its jurisdiction, as

33 Daphne Barak-Erez, Israel: The Security Barrier - Between International Law, Constitutional Law, and Domestic Judicial Review (Oxford University Press, Oxford, 2006), pp. 540-552. 
well as more general principles of criminal procedure. ${ }^{34}$ Secondly, the Court applies 'where appropriate, applicable treaties and the principles and rules of international law, including the established principles of the international law of armed conflict'.35 A third source of applicable law, that is not directly relevant to the issue at hand, is mentioned in Section 21(1)(c) Rome Statute, and consists of 'general principles of law derived (...) from domestic laws of legal systems of the world'. ${ }^{36}$ The enumeration of Article 21(1) Rome Statute is considered to establish a hierarchical structure of sources, meaning that only if the Statute does not provide sufficient clarity, the Court will apply a treaty as meant in Section $(1)(b)$. Only if the examination of treaties also fails to offer a solution to the question the Court has to address, will the Court turn to observing principles of domestic law pursuant to Section (1)(c). ${ }^{37}$

The integral text and structure of Article 21 Rome Statute resembles Article 38 of the ICJ Statute, which lists those instruments that are to be considered sources of international law. More specifically, the instruments mentioned in Article 21(1)(b) can be considered to comprise all those sources which Article 38 of the ICJ Statute qualifies as norms of international law, without imposing an explicit hierarchy amongst them. ${ }^{38}$ In that sense, Sections (1)(a) and (1)(b) warrant the interpretation that the ICC applies all the norms of international law that are defined by Article 38 of the ICJ Statute, while giving primacy to its own Statute and related instruments. The ICC then utilizes these norms as interpretative instruments in the course of establishing whether all the elements of a crime as defined by the Statute, obtains. ${ }^{39}$

The question whether a territory is occupied: the existence of an occupation as one of the criteria for the fulfilment of Article 8(2)(b)(viii) Rome Statute, is by its nature a question predominantly governed by law rather than by fact. Therefore, the Court will have to find an answer to this question primarily

34 Margaret McAuliffe de Guzman, 'Article 21', in Otto Triffterer (ed.), Commentary on the Rome Statute of the International Criminal Court (Nomos Verslagsgesellschaft, BadenBaden, 1999), pp. 436, 439 .

35 Article 21(1)(b) Rome Statute.

36 Ibid.

37 De Guzman, supra note 34, pp. 436-437, 440-442; Petra Vieblig, Illicitly Obtained Evidence at the International Criminal Court (Asser Press, The Hague, 2016), pp. 23-24.

38 Ibid., pp. 13-14; Aldo Zammit Borda, 'A Formal Approach to Article 38(1)(d) of the ICJ Statute from the Perspective of the International Criminal Courts and Tribunals', (24)(2) The European Journal of International Law (2013) 649-661, <www.ejil.oxfordjournals.org/ content/24/2/649.full.pdf>, 23 August 2017.

39 Leena Grover, Interpreting Crimes in the Rome Statute of the International Criminal Court (Cambridge University Press, Cambridge, 2014), pp. 175-176. 
based upon the instruments of law it has at its disposal pursuant to Article 21 Rome Statute, with due regard to its internal hierarchy and in accordance with Article 38 ICJ Statute. The Statute itself offers no solution to this question. Therefore, the Court has to resort to applying applicable treaties where appropriate, pursuant to Article 21(1)(b) Rome Statute.

This article now turns to the question whether the 1920 and 1922 treaties qualify as treaties in the sense of Article 21(1)(b) Rome Statute, and whether it is appropriate to apply them in assessing the legal status of the West Bank. It is tenable that the ОтP, when assessing a reasonable basis to proceed with an investigation pursuant to Article 53(1) Rome Statute, notwithstanding its discretionary powers to discern the sources of law for such basis, anticipates the application of Article 21(2) Rome Statute by the Court. It would be illogical for a prosecutor to ignore sources of law the ICC might apply once an investigation proceeds to trial. The preceding question however, is whether the instruments of 1920 and 1922 qualify as 'treaties' within the meaning of Article 21(2) Rome Statute.

\subsection{Law-making Treaties}

When assessing the potential binding nature of treaties akin to those of 1920 and 1922, one cannot ignore the influence of Article 38 of the ICJ Statute. As seen above in Section 2.1, this article is generally perceived as an authoritative statement of the sources of international law. ${ }^{40}$ Article 38 enumerates four sources of law, which are as such not promulgated as to represent a hierarchy. ${ }^{41}$ Paragraph 1 of Article 38 lists four categories of sources with (a) being 'international conventions, whether general or particular, establishing rules expressly recognized by the contesting States; and (b) international custom, ${ }^{42}$ as evidence of a general practice accepted as law'.43 As analysed by Brownlie:

[i]n practice, the Court may be expected to observe the order in which they appear: (a) and (b) are obviously the important sources, and the

\footnotetext{
40 Malcolm Shaw, International Law (Cambridge University Press, Cambridge, 2014), p. 50.

41 Ian Brownlie: Principles of Public International Law (Clarendon Press, Gloucestershire, 1990), p. 3 .

42 For a better understanding of the nature of custom see e.g., the Lotus case, 7 September 1927, International Court of Justice, paras. 45-48; the Nicaragua (Merits) case, 27 June 1986, International Court of Justice, paras. 172-178, 183-186, 188-193; and the Legality of the Treat or Use of Nuclear Weapons case, 8 July 1996, International Criminal Court, Advisory Opinion, paras. $64-72$.

Article $38(1)$ Statute of the International Court of Justice.
} 
priority of (a) is explicable by the fact that this refers to a source of mutual obligations of the parties. ${ }^{44}$

The question arises as to the nature of the 1920 and 1922 instruments. In 1962, a provisional draft of the International Law Commission provided the following definition of a treaty as being:

any international agreement in written form, whether embodied in a single instrument or in two or more related instruments and whatever its particular designation (treaty, convention, protocol, covenant, charter, statute, act, declaration, concordat, exchange of notes, agreed minute, memorandum or agreement, modus vivendi or any other appellation), concluded between two or more States or other subjects of international law and governed by international law. 45

Arguably, the 1920 and 1922 treaties fulfil this definition.

A second observation in this regard is that treaties are in principle only binding on the contracting parties. ${ }^{46} \mathrm{~A}$ State party cannot be bound to a treaty if it has not (yet) signed and ratified that treaty. ${ }^{47}$ This could mean that the 1920 and 1922 treaties would only be binding on the five Allied Powers. Yet, the declaratory nature of the provisions of these treaties may produce a persuasive 'law-creating effect' akin to a customary rule..$^{48}$ It has to be noted that the treaties of 1920 and 1922 qualify as 'law making treaties' in that they invoke general norms for the future conduct of the parties, while the non-parties to these treaties by their conduct in 1948 - the transition of the League of Nations into the UN - seem to have accepted the provisions and norms thereto. ${ }^{49}$ In conclusion, it can be said that - as a preliminary observation - the treaties of 1920 and 1922, being law-making, 'might have a direct effect on the content of the law'50 and thus on the transposition of Article 21(2) of the ICC Statute onto Article 53(1) of this Statute. The following section will delve into this effect.

\footnotetext{
44 Brownlie, supra note 41.

45 Yearbook of the International Law Commission (162-ii), pp. 31-32, <www.legal.un.org/ilc/ publications/yearbooks/english/ilc_1962_v2.pdf >, 21 August 2017.

46 Brownlie, supra note 41, p. 12.

47 Shaw, supra note 40, p. 68. This general rule was illustrated in the North Sea Continental Shelfs case (20 February 1969), International Court of Justice, paras. 6o-82, <www.icj-cij .org/files/case-related/51/051-19690220-JUD-o1-0o-EN.pdf>, 21 August 2017.

48 See Brownlie, supra note 41, p. 67.

49 See for the nature of law-making treaties, Brownlie supra note 41, p. 12; and Shaw, supra note 40, pp. 67-68.

5o See for this effect: Brownlie, ibid., p. 11.
} 


\subsection{The (Non-) Continuance of the 1920 and 1922 Treaties}

After having examined the potential direct effect or influence of the 1920 and 1922 treaties on the content of law, this section discusses the question whether the 'law-making' nature thereof was amplified after the adoption of these treaties. Furthermore, it addresses the question of their law-binding nature in view of Articles 35 and 36 of the main instrument that regulates treaties; the Vienna Convention on the Law of Treaties (VCLT) of 1969. Although the VCLT was adopted more than 40 years after the drafting of both the Balfour Declaration and the San Remo Resolution, its rules and obligations do apply to both treaties, as the VCLT contains principles of an international customary nature.

As to the first question, it has to be observed that the 1920 and 1922 treaties do not include a unilateral denunciation clause, nor were they otherwise suspended or terminated. Under the VCLT, the validity and continuance of a treaty and of consent to be bound by it, is presumed. ${ }^{51}$ Moreover, grounds of invalidity thereof must be invoked by a party, which did not occur thereto. ${ }^{52}$ Concerning the second question, the situation is more complex. The principle of pacta tertiis nec nocent nec prosunt dictates that the obligations and rights invoked by a treaty only apply between the parties to it. ${ }^{53}$ This is expressed by Article 34 VCLT, saying that 'a treaty does not create either obligations or rights for a third state without its consent. ${ }^{54}$ As to the treaties of 1920 and 1922, this could imply that 'a right to a Jewish homeland' would initially only accord an obligation to the five Allied Powers. These treaties, as mentioned before, constitute an 'objective regime' as to a territory, which is not without controversy when it concerns the position of third states. ${ }^{55}$ Two provisions of the VCLT merit thought:

(i) Article 35 sets forth the requirement of the third state in order to be bound by a treaty, expressly accepting the obligation enshrined by the treaty, unless the rule in question became part of customary law. ${ }^{56}$ In the instant case, the third states, other than the Allied Powers, did not expressly accept said obligations.

(ii) On the other hand, Article 38 of the VCLT constitutes a presumption of consent of the third state, saying that a right arises for a third state from a provision of a treaty if the parties to the treaty intend the provision

\footnotetext{
$5^{1}$ Article 42 Vienna Convention on the Law of Treaties.

52 Ibid., Section 2.

53 Brownlie, supra note 41, p. 622.

54 Article 34 Vienna Convention on the Law of Treaties.

55 Brownlie, supra note 41, p. 623.

$56 \quad$ Ibid.
} 
to accord that right either to the third state, or to a group of states to which it belongs, or to all states, and the third state assents thereto. Its assent shall be presumed so long as the contrary is not indicated, unless the treaty otherwise provides. ${ }^{57}$

In the instant case, as mentioned before, the rights and obligations promulgated were not tacitly or explicitly revoked or modified after 1920 and 1922. Moreover, in 1948, the rights and obligations incurred by the League of Nations were succeeded by the UN. Yet seemingly, several reservations should be made:

(i) Article 80 of the UN Charter provides for a presumption of succession of the 1920 and 1922 treaty obligations by the UN. ${ }^{58}$

(ii) Yet, the term 'national home' as set forth in said treaties lacks a uniform definition, while this 'home' was made subject to 'suitable conditions' and contained safeguards for the rights and position of the non-Jewish communities. ${ }^{59}$

(iii) Thirdly, at the UN San Francisco Conference (April-June 1945), the UN did not accept the request of the Jewish Agency to prevent an alteration of the right to Jewish nationhood as secured by the Balfour Declaration and the Mandate. Instead, the UN stipulated in the context of Article 80 UN Charter that it had the power to enter into trusteeship agreements that could alter existing rights created by a mandate. ${ }^{60}$

(iv) Fourthly, UNGA resolution 24(1) reserved the right of the UN not to assume any function or power of the League of Nations. ${ }^{61}$

(v) Fifthly, the British White Paper of 1922, accepted by the Zionist Congress in 1921, which clarified the mandate's text in that the Balfour Declaration does '(...) not contemplate that Palestine as a whole should be converted

57 Cf. Ibid., p. 624.

$5^{8} \quad C f$. the Levy Report of 9 July 2012 according to Lorenzo Kamel, The Palestinian Territories and The (Self)legitimization of the Settlements (e-international relations, 14 February 2014), $<$ www.e-ir.info/2014/02/14/the-palestinian-territories-and-the-selflegitimizazion-of -the-settlements/>, 21 August 2017; the authors remark that the Levy Rapport has not been received without controversy by the international community. While opinions may vary on the objectivity of the rapport, it may still prove to be educational.

59 Lorenzo Kamel, The Palestinian Territories and The (Self)legitimization of the Settlements (e-international relations, 14 February 2014), <www.e-ir.info/2014/02/14/the-palestinian -territories-and-the-selflegitimizazion-of-the-settlements/>, 21 August 2017.

6 Ibid.

61 Ibid. 
into a Jewish national home, but that such a home should be founded in Palestine.' ${ }^{62}$

In conclusion, based on Article 36 of the VCLT and in view of the abovementioned reservations, it is not without saying that the 1920 and 1922 treaties are per se binding within the ambit of Article 21(1) Rome Statute. At the same time, these reservations do not exclude the proliferation of 'homeland' rights within the 'occupied territories'. Accordingly, the mentioned treaties remain sources of international law that cannot be overlooked.

\section{Anticipatory Interpretation of Article 21 Within the Investigative Ambit of Article 53(1) Rome Statute}

This issue became topical in light of the preliminary examination into the situation in Palestine. Before the Prosecution initiates an official investigation, it conducts a preliminary examination to assess whether the information is such that a reasonable basis exists to open a subject-matter investigation. ${ }^{63}$ Since Palestine was granted a 'non-member observer state' status in the UN on 29 November 2012, ${ }^{64}$ Palestine was able to accede to the Rome Statute on 2 January 2015.65 Palestine then lodged a declaration pursuant to Article 12(3) Rome Statute accepting the jurisdiction of the ICC on 1 January 2015, relating to alleged crimes committed in the 'occupied Palestinian Territory, including East Jerusalem, since 13 June 2014, ${ }^{66}$ marking the start of the Operation Protective Edge by the Israeli Defense Force. ${ }^{67}$ By choosing 13 June 2014 as a starting

$62 \quad$ Ibid.

63 International Criminal Court, The Office of the Prosecutor, Policy Paper on Preliminary Examinations (November 2013), p. 2, para. 1, <www.icc-cpi.int/itemsDocuments/OTP\%20 Preliminary\%2oExaminations/OTP\%20-\%2oPolicy\%2oPaper\%2oPreliminary\%20 Examinations\%20\%202013.pdf $>$, 21 August 2017.

64 United Nations General Assembly, Status of Palestine in the United Nations (A/REs/67/19), para. 2, <www.unispal.un.org/DPA/DPR/unispal.nsf/o/19862Do3 C564FA2C85257ACBoo 4 EE6gB $>, 21$ August 2017.

65 United Nations, Instrument of Accession (C.N.13.2015.TREATIES-XVIII.10), <www.treaties .un.org/doc/Publication/CN/2015/CN.13.2015-Eng.pdf>, 21 August 2017.

66 The Palestine National Authority, Declaration Accepting the Jurisdiction of the International Criminal Court, (31 December 2014) <www.icc-cpi.int/iccdocs/PIDS/press/ Palestine_A_12-3.pdf $>$, 21 August 2017.

67 International Criminal Court, The Office of the Prosecutor, Report on Preliminary Examination Activities 2016 (14 November 2016), para. 114, <www.icc-cpi.int/iccdocs/otp/161114 -otp-rep-PE_ENG.pdf>, 18 August 2017. 
date for the preliminary examinations, the Palestinian Government expressly included the 'Gaza conflict'.

In the Report on Preliminary Activities 2016 issued by the отP, a list of potential crimes allegedly committed by both parties to the 2014 Gaza conflict, in particular committed since 13 June 2014, is included. ${ }^{68}$ This list of potential crimes entails acts such as the use of protected persons as shields, ill-treatment of persons accused of being collaborators, attacks against residential buildings and civilians, attacks against medical facilities and personnel, attacks against United Nations Relief Works Agency schools, but also 'settlement activities'.69 In this regard, the отр seems to presuppose the situation on the West Bank as being potentially 'occupied' by Israel. Specifically, the oTP focusses on the potential application of Article 8(2)(b)(viii) Rome Statute that criminalizes 'the transfer, directly or indirectly, by the Occupying Power of parts of its own civilian population into the territory it occupies, or the deportation or transfer of all or parts of the population of the occupied territory within or outside this territory' 70

Arguably, Article 8(2)(b)(viii) derives from Article 49 of the Fourth Geneva Convention (GC IV). Article 49 GC IV prohibits the 'deportations or transfers of part of the Occupying Power's own civilian population into the territory it occupies. ${ }^{71}$ Article 8(2)(b)(viii) is identical to Article 85(4)(a) of Protocol I GC, except for the use of words 'direct or indirect' and a reference to Article 49 GC IV. ${ }^{72}$ The deviation from the wording of the GC compared to Article 8 Rome Statute has been intended to clarify that indirect transfer policies such as facilitations or financial grants are also punishable under international criminal law. ${ }^{73}$ Indirect transfer policies are those that induce the population of the occupying power to settle in the occupied territory. ${ }^{74}$ An essential element of the prohibition set forth in Article 8(2)(b)(viii) Rome Statute is the reference to the commission by an occupying power. Palestine seems to argue that Israel, as an occupying power, violated Article 8(2)(b)(viii) of the Rome Statute. To put it differently, Palestine argues that the territory was not Israel's to claim. Conversely, if Israel could not be classified as an occupying power, a constitutive element

\footnotetext{
68 International Criminal Court, supra note 3, para. 119-134.

69 Ibid.

70 Article 8(2)(b)(viii) Rome Statute.

71 Article 49 Geneva Convention Relative to the Protection of Civilian Persons in Time of War (Fourth Geneva Convention) (75 UNTs 287).

72 Michael Cottier, 'Article 8', in: Triffterer (ed.), supra note 34, p. 210.

73 Ibid., p. 214.

74 Ibid., p. 213.
} 
of Article 8(2)(b)(viii) would be absent. The historical context arguably shows that the question whether Israel can be classified as an occupying power is still a legally valid one. In turn, this triggers the question whether the отр should take this historical context into account in its preliminary examination.

The question arises how the OTP, within its assessment pursuant to Article 53(1) Rome Statute, has to establish whether a situation of 'occupation' occurs. It is not unlikely that the ОтP will determine the element of 'occupied territory' in said provision on the basis of contemporary findings by the ICJ and the uN Security Council. In its Advisory Opinion of 9 July 2004 on the Legal Consequences of the Construction of a Wall, the ICJ qualified the situation in the West Bank as 'occupation'75 It held that Israel acquired possession over these territories through an (aggressive) war. ${ }^{76}$ Moreover, the ICJ ascertained the rationale of the GC IV, being to protect civilians, irrespective of the (prior) status of the territories in question and irrespective of any potential prior sovereignty rights over the West Bank assumed by Jordan. ${ }^{77}$

In line with the ICJ, UN Security Council resolution 2334 equally portrays the situation in the West Bank as occupation, holding that Israel violates international law by establishing settlements in that region. ${ }^{78}$ The question merits thought as to whether the ОтP, discerning the criterion of 'a reasonable basis to proceed with an investigation' pursuant to Article 53(1) Rome Statute, is bound by the findings of the ICJ's Advisory Opinion and those of the UN Security Council in this regard, or whether it could depart from these findings. At the outset, it can be observed that neither resolutions of the Security Council or Advisory Opinions are enumerated in the sources of law as set forth in Article 38(1) of the ICJ Statute or Article 21 of the Rome Statute.

The mentioned Advisory Opinion and Security Council resolution fail to address an analysis of the 1920 and 1922 treaties, and their potential impact on the territorial claims within the 'occupied territories' is absent. In light of the interrelationship between Articles 21 and 53(1) Rome Statute, the potential law-making effect of said treaties could be a determinative factor when ascertaining the foundation to proceed with an investigation vis-à-vis Article $8(2)$ (b)(viii) Rome Statute. If the OTP anticipates the application of Article 21

75 Legal Consequences of the Construction of a Wall, 9 July 2004, International Court of Justice, Advisory Opinion, para. 101, <www.icj-cij.org/files/case-related/131/131-20040709 -ADV-o1-0o-EN.pdf>, 21 August 2017.

76 Ibid., paras. $73,101$.

77 See for example ibid., para. 95.

78 United Nations Security Council, Resolution 2334 (2016) (s/RES/2334), paras. 1, 2 and 9, <www.un.org/webcast/pdfs/SRES2334-2016.pdf>, 21 August 2017. 
Rome Statute within the confines of Article 53(1) Rome Statute, it will trigger two conflicting views as to the status of the West Bank. It is not unlikely that the Отр will attach more weight to the ICJ's AO since it reflects the view albeit not a legally binding opinion - of the UN's principal judicial organ. Yet the other view that culminates from the 1920 and 1922 treaties should at the least be part of the отр's preliminary examination, or, when applicable, a formal investigation. The 1920 and 1922 treaties could provide a presumption of Israel's legal claim to sovereignty over the Old City of Jerusalem and potentially the West Bank, based on the rights granted to the sacred trust contained in the Mandate. Especially now that it is legally not to be excluded that in 1948 the UN took over those rights from the League of Nations.

\section{4}

\section{Conclusion}

The preceding sections show the existence of a discrepancy in legal-historic understanding between the views of some scholars vis-à-vis the qualification of the West Bank as 'occupied territory' on the one hand, and contemporary legal opinions reflected by the ICJ. This article discerns the legal-political question whether the 1920 and 1922 treaties could govern the preliminary examination of the отр into the Palestine situation. To this end, first the legal standing of those instruments was assessed. It was observed that these instruments (still) qualify as 'treaties', and were as such not annulled, albeit that several legal reservations to this binding nature can be made. After having determined this legal standing, it was observed that international conventions and 'applicable treaties' as meant by Article 21(2) Rome Statute may play a decisive role within the decision-making process pursuant to Article 53(1) Rome Statute by the отр. This might especially be relevant with respect to the preliminary examination in light of the situation in Palestine, since one of the investigative aims is to determine a potential infraction of Article 8(2)(b)(viii) of the Rome Statute; a provision that seems to be subjected to a rather extensive interpretation.

Article 53(1) Rome Statute, although granting the отP discretionary powers in how to ascertain the existence of 'a reasonable basis to prosecute', might justify an anticipatory interpretation of Article 21(2) Rome Statute, when it is to be foreseen that the ICC could apply treaty law to dissolve a legal dispute. In the Palestine situation, this anticipatory effect might arise now that the validity of a treaty and its continuance in force 'may be impeached only through the application of the present Convention' ${ }^{79}$ Articles $65^{-68}$ of the VCLT set forth

Vienna Convention on the Law of Treaties 1969, Article 42(1). 
the procedure to be followed with respect to the invocation of the validity, termination, withdrawal, or suspension of a treaty. Such a procedure was yet not invoked with regard to the 1920 and 1922 treaties. Therefore, procedurally, the treaties - as it is tenable - still could have legal standing. The central component of Article 8(2)(b)(viii) is that of the 'territory it occupies'. The historical data which underlie the 1920 and 1922 treaties merit that the отр balances the law-making effect thereof with contemporary views on the situation in the West Bank as set forth by the ICJ and the UN Security Council. 